\title{
Role of $\mathrm{HCA}_{2}$ in Regulating Intestinal Homeostasis and Suppressing Colon Carcinogenesis
}

\author{
Zhuoyue Li, Kayleen J. McCafferty and Robert L. Judd* \\ Department of Anatomy, Physiology and Pharmacology, College of Veterinary Medicine, Auburn University, Auburn, AL, \\ United States
}

Hydroxycarboxylic acid receptor $2\left(\mathrm{HCA}_{2}\right)$ is vital for sensing intermediates of metabolism, including $\beta$-hydroxybutyrate and butyrate. It also regulates profound anti-inflammatory effects in various tissues, indicating that $\mathrm{HCA}_{2}$ may serve as an essential therapeutic target for mediating inflammation-associated diseases. Butyrate and niacin, endogenous and exogenous ligands of $\mathrm{HCA}_{2}$, have been reported to play an essential role in maintaining intestinal homeostasis. $\mathrm{HCA}_{2}$, predominantly expressed in diverse immune cells, is also present in intestinal epithelial cells (IECs), where it regulates the intricate communication network between diet, microbiota, and immune cells. This review summarizes the physiological role of $\mathrm{HCA}_{2}$ in intestinal homeostasis and its pathological role in intestinal inflammation and cancer.

OPEN ACCESS

Edited by:

Pinyi Lu,

Frederick National Laboratory for Cancer Research $(\mathrm{NIH})$, United States

Reviewed by:

Anastasia N. Vlasova, The Ohio State University, United States

Laura Baldomà

University of Barcelona, Spain

${ }^{*}$ Correspondence:

Robert L. Judd

juddrob@auburn.edu

Specialty section:

This article was submitted to Nutritional Immunology, a section of the journal

Frontiers in Immunology

Received: 14 September 2020 Accepted: 05 February 2021

Published: 23 February 2021

Citation:

Li Z, McCafferty KJ and Judd RL

(2021) Role of $\mathrm{HCA}_{2}$ in Regulating Intestinal Homeostasis and Suppressing Colon Carcinogenesis. Front. Immunol. 12:606384. doi: 10.3389/fimmu.2021.606384
Keywords: $\mathrm{HCA}_{2}$, intestinal homeostasis, anti-inflammatory, intestinal inflammation, colon cancer, mucosal immunity, microbiota

\section{INTRODUCTION}

The intestinal tract is an organ system with specialized architecture that functions to digest food, and extract and absorb energy and nutrients. It also secretes over 20 different hormones and harbors more than 640 different species of bacteria (1). Physiological and pathophysiological events that trigger the breakdown of intestinal homeostasis negatively impact intestinal health, and may result in intestinal disorders including inflammatory bowel disease (IBD) and colitis-associated cancer. $\mathrm{IBD}$ is a chronic and life-threating disease characterized by prolonged inflammation of the digestive tract $(2,3)$. IBD encompasses two conditions, Crohn's disease and ulcerative colitis. Crohn's disease can affect any part and layer of the gastrointestinal tract, while ulcerative colitis is usually limited to the innermost layer of the colon and rectum (4). Both Crohn's disease and ulcerative colitis are characterized by episodes of fatigue, abdominal cramping, rectal bleeding, diarrhea, weight loss, and the influx of immune cells that produce cytokines, proteolytic enzymes, and free radicals $(5,6)$. Patients with IBD are at increased risk of developing colitis-associated cancer which is difficult to treat and has high mortality $(>50 \%)(7,8)$. In 2015 , an estimated $1.3 \%$ of US adults reported living with IBD, with cases increasing worldwide $(9,10)$. The global spread of IBD is associated with the host genetic background, intestinal microbiota, diets, environments and immunological dysregulation $(4,11,12)$.

The intestinal tract represents the largest compartment of the immune system in the body (13), with intestinal health implicated in controlling disease development not only within itself but also throughout the body. To maintain intestinal homeostasis, a multi-pronged approach including the immune system, microbial ecosystem and diet is necessary. A versatile receptor, hydroxycarboxylic acid receptor $2\left(\mathrm{HCA}_{2}\right)$, is capable of both nutrient sensing and immunomodulation, lending to its popularity as a potential target for the promotion of intestine health. 
In 1993, $\mathrm{HCA}_{2}$ was identified as an orphan receptor (GPR109A) $(14,15)$, and later described in mice as a "protein upregulated in macrophages by interferon-gamma (IFN- $\gamma$ )" (PUMA-G) (16). In 2003, several studies reported that $\mathrm{HCA}_{2}$ is a receptor for niacin and functions to mediate its antilipolytic effects in adipocytes (17-19). Benyó et al. and Hanson et al. subsequently demonstrated that binding of niacin to $\mathrm{HCA}_{2}$ on Langerhans cells and keratinocytes is also responsible for the niacin-induced cutaneous flushing reaction, involving release of prostaglandin $\mathrm{D}_{2}\left(\mathrm{PGD}_{2}\right)$ and prostaglandin $\mathrm{E}_{2}\left(\mathrm{PGE}_{2}\right)(20$, $21)$. In 2005 , the ketone body $\beta$-hydroxybutyrate $(\beta-\mathrm{OHB})$ was identified as an endogenous ligand of $\mathrm{HCA}_{2}$ (22). This resulted in the deorphanization of the receptor, which was subsequently renamed hydroxycarboxylic acid receptor $2\left(\mathrm{HCA}_{2}\right)$ (23). Most recently, butyrate, a short-chain fatty acid (SCFA) bacterial product in the colon lumen generated at high concentrations (10-20 mM) from dietary fiber fermentation, was recognized as an endogenous ligand of $\mathrm{HCA}_{2}$ (24). Butyrate activation of $\mathrm{HCA}_{2}$ plays an important role in the maintenance of intestinal homeostasis (24). New synthetic ligands of $\mathrm{HCA}_{2}$ have been developed, such as acipimox, GSK256073 and derivatives of pyrazole-3-carboxylic acid or cyclopentapyrazole (25-27).

$\mathrm{HCA}_{2}$ is widely expressed in various tissues and cell types, including adipose tissue, spleen, lung, lymph node and intestine. $\mathrm{HCA}_{2}$ is predominantly expressed not only in both white and brown adipocytes, but also in diverse immune cells, including dendritic cells (DCs), monocytes, macrophages, neutrophils and epidermal Langerhans cells, but not lymphocytes $(16,18$, $21,28,29)$. Interestingly, several cytokines show the ability to regulate the expression of $\mathrm{HCA}_{2}$ in immune cells. $\mathrm{HCA}_{2}$ expression is upregulated in macrophages and monocytes after IFN- $\gamma$ treatment (16), and the expression of $\mathrm{HCA}_{2}$ in macrophages is significantly increased by proinflammatory stimulants lipopolysaccharide (LPS), interleukin (IL)-6 and IL$1 \beta$ (30). Colony-stimulating factor 2 (CSF2) increases $\mathrm{HCA}_{2}$ expression level in neutrophils (29). $\mathrm{HCA}_{2}$ is also present in intestinal epithelial cells (IECs), retinal pigment epithelium, hepatocytes, keratinocytes and microglia (21, 31-34). Notably, both mRNA and protein levels of $\mathrm{HCA}_{2}$ in IECs are drastically reduced in germ-free mice compared to conventional mice, due to the absence of gut bacteria. These changes are reversed when the intestinal tract of germ-free mice is re-colonized (35).

While the anti-lipolytic effects of $\mathrm{HCA}_{2}$ are well-known, more recent studies have demonstrated that activation of $\mathrm{HCA}_{2}$ by endogenous and exogenous ligands is associated with antiinflammatory effects in numerous disease states $(25,31,36-41)$. Early studies showed that activation of $\mathrm{HCA}_{2}$ in various cell types could trigger different downstream signaling events and effects (26) (Figures 1A-F). In adipocytes, activation of $\mathrm{HCA}_{2}$ inhibits lipolysis $(18,42,43)$ (Figure 1A). In hepatocytes, $\mathrm{HCA}_{2}$ mediates hepatic de novo lipogenesis and decreases lipid accumulation in liver $(44,45)$ (Figure 1B). In IECs, ligand binding to $\mathrm{HCA}_{2}$ activates NOD-, LRR- and pyrin domain-containing protein 3 (NLRP3) inflammasome, which promotes the maturation of IL-18 for secretion $(46,47)$ (Figure 1C). IL-18 is a critical effector molecule in intestinal disorders and is required for IEC proliferation (48). $\mathrm{HCA}_{2}$ also suppresses basal and LPS-induced nuclear factor-kappa B (NF- $\kappa \mathrm{B})$ activation in normal and cancer colonocytes (24) (Figure 1C). In retinal pigment epithelium, $\mathrm{HCA}_{2}$ exerts dual effects depending on the concentration of the agonist. 4-hydroxynonenal, an $\mathrm{HCA}_{2}$ agonist, can induce either an anti-inflammatory response or apoptosis (49) (Figure 1D). In Langerhans cells, $\mathrm{HCA}_{2}$ causes cutaneous flushing reaction $(20,21)$ (Figure 1E). In macrophages, activation of $\mathrm{HCA}_{2}$ exerts an anti-inflammatory effect $(50,51)$ (Figure 1F). $\mathrm{HCA}_{2}$ also represses chemokine-induced migration of macrophages (30) (Figure 1F). $\mathrm{HCA}_{2}$ shows anti-inflammatory effects in microglia and human monocytes (52-54) (Figure 1F). In DCs, $\mathrm{HCA}_{2}$ activation decreases IL-6 levels and increases IL-10 levels and upregulates expression of RALDH1, which synthesizes retinoic acid (RA) from retinol. RA is necessary for promoting regulatory $\mathrm{T}$ cells (Tregs) function and proliferation, especially in the gut in both murine and human DCs (55-57) (Figure 1F). In neutrophils, niacin-mediated $\mathrm{HCA}_{2}$ activation increases $\mathrm{Bcl}-2$ associated agonist of cell death (BAD) levels, a pro-apoptotic member of the Bcl-2 family (58) (Figure 1F). Collectively, these studies clearly demonstrate that $\mathrm{HCA}_{2}$ plays a critical role in nutrient sensing and host protection against pro-inflammatory insults in multiple cell types using various signaling mechanisms.

\section{INTESTINAL HOMEOSTASIS AND HCA : IMMUNE CELLS, INTESTINAL EPITHELIUM, MICROBIOME, AND METABOLITES}

The intestinal tract, comprised of small intestine, large intestine/colon, and rectum, is the central location for nutrient and water absorption. It harbors more than $10^{13}$ microorganisms, contains over 20 different hormones, and serves as the single largest immune compartment in the body $(13,59)$. Consequently, building and maintaining a homeostatic intestinal tract is a highly complex and broad concept that encompasses a multi-disciplinary approach including the immune system, host cells, gut microbiota and nutrients. Further complexity arises from the mutual interactions between the intestinal tract and other organ systems.

The intestinal mucosa, a crucial site of innate and adaptive immune regulation, is comprised of IECs, lamina propria and muscularis mucosa (Figure 2). IECs are specialized epithelia comprised of many different cell types: epithelial stem cells which continuously self-renew by dividing and generate all differentiated intestinal cell types, enterocytes which absorb water and nutrients, goblet cells which secrete mucins to form a mucus layer boundary between the gut microbiota and host tissue, Paneth cells which secrete anti-microbial peptides, enteroendocrine cells which secrete hormones and cytokines capable of systemic or local effects, and microfold cells ( $\mathrm{M}$ cells) which connect to the intestinal lymphoid follicles (60-63). The intestinal epithelium is bound together by tight junction proteins, which regulate the paracellular permeability and are essential for the integrity of the epithelial barrier. Tight junction proteins prevent harmful substances such as LPS, foreign antigens, toxins and microorganisms from entering into the blood stream (64). 


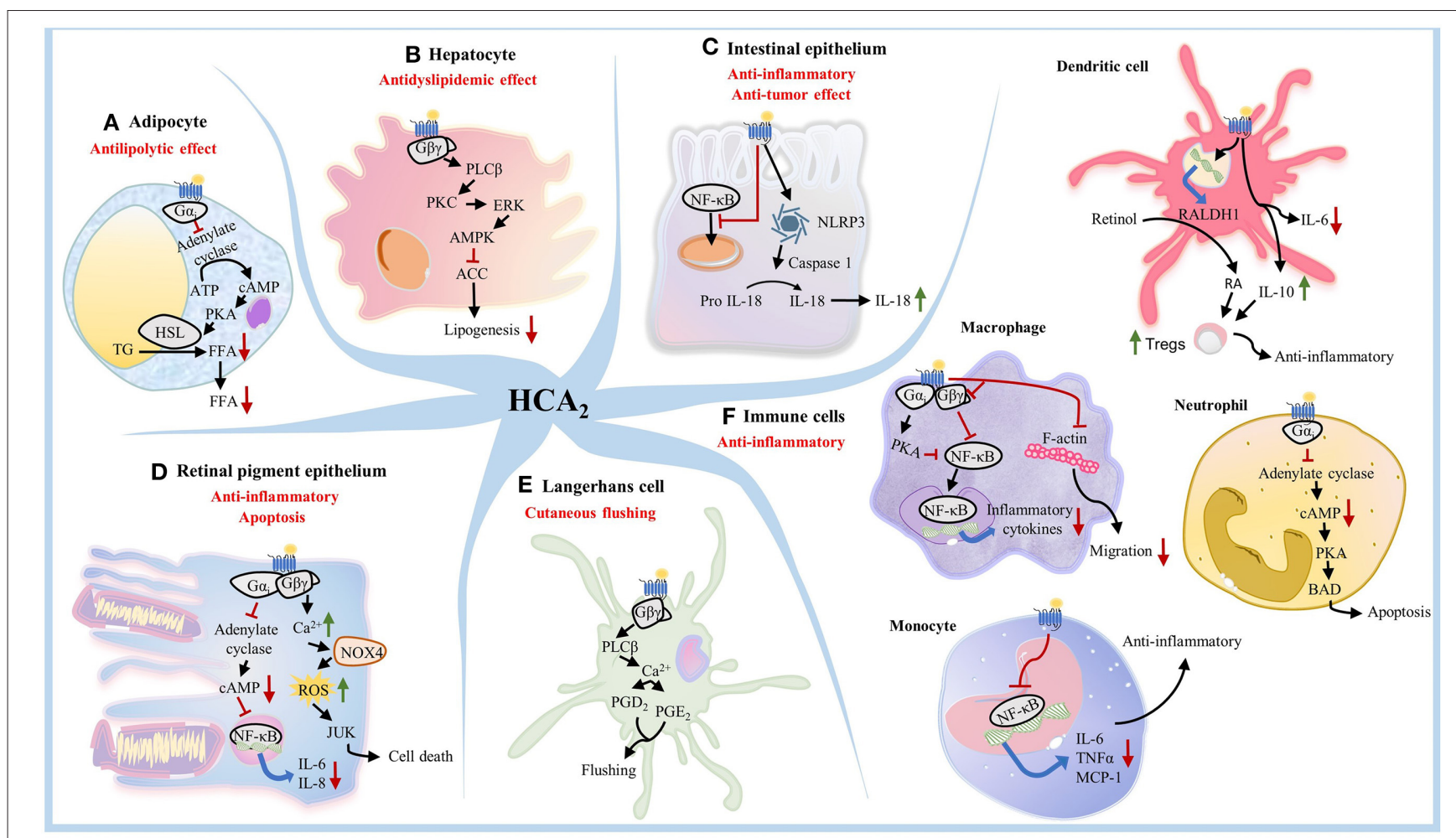

inglif $\mathrm{HCA}_{2}$ Ligand

FIGURE 1 | $\mathrm{HCA}_{2}$ triggers different downstream signaling pathway in different cell types. (A) In adipocytes, activation of $\mathrm{HCA}_{2}$ triggers a Gai-mediated inhibition of adenylate cyclase activity, which leads to lower intracellular cAMP levels, reduced protein kinase A (PKA) activity, and further reduces the activity of hormone sensitive lipase (HSL), an important lipolytic enzyme. This inhibition of lipolysis results in a decreased release of free fatty acids into the circulation. (B) In hepatocytes, activation of $\mathrm{HCA}_{2}$ mediates the protein kinase $\mathrm{C}$ (PKC)-extracellular signal-regulated kinase (ERK) signaling pathway, leading to phosphorylation of AMP-activated protein kinase (AMPK) and inhibition of acetyl CoA carboxylase (ACC). This results in an inhibition of hepatic de novo lipogenesis and a remarkable decrease of lipid accumulation in liver. (C) In colonocytes, ligand binding to $\mathrm{HCA}_{2}$ suppresses NF-KB activation and activates NLRP3 inflammasome, which recruits caspase-1 and promotes the maturation of IL-18 for secretion. (D) In retinal pigment epithelium, $\mathrm{HCA}_{2}$ exerts either an anti-inflammatory response through the Gai/cAMP/NF-kB pathway, or apoptosis through the $\mathrm{G} \beta \gamma / \mathrm{Ca}^{2+} / \mathrm{NOX} 4 / \mathrm{ROS} / \mathrm{JNK}$ pathway. (E) Within Langerhans cells, $\mathrm{HCA}_{2}$-mediated $\mathrm{G}_{\mathrm{i}}$ activation primarily results in the $\mathrm{G} \beta \gamma$-complex released from activated $\mathrm{G} \alpha_{\mathrm{i}}$, thereby increasing intracellular calcium concentration by mobilizing $\mathrm{Ca}^{2+}$ release from the endoplasmic reticulum and ultimately driving the formation of $\mathrm{PGD}_{2}$ and $\mathrm{PGE}_{2}$, which are released to the dermal layer and cause cutaneous flushing reaction. (F) In macrophages, activation of $\mathrm{HCA}_{2}$ involves inhibition of NF-kB, thereby exerting an anti-inflammatory effec. $\mathrm{HCA}_{2}$ activation in macrophages also represses $\mathrm{F}$-actin and blocks G $\beta \gamma$ signaling to inhibit chemokine-induced migration of macrophages. $\mathrm{HCA}_{2}$ also shows anti-inflammatory effects in Parkinson's disease models by inhibiting the phosphorylation of the NF- $\mathrm{kB}$ p65 signaling pathway in microglia. $\mathrm{HCA}_{2}$ suppresses LPS-induced NF- $\mathrm{kB}$ activation in human monocytes, resulting in decreased transcription of IL-6, TNF $\alpha$, and MCP-1. In DCs, $\mathrm{HCA}_{2}$ activation decreases IL-6 level and increases IL-10 level, also upregulates expression of RALDH1, which synthesizes RA from retinol. RA and IL-10 promote Treg cell proliferation. In neutrophils, niacin-mediated $\mathrm{HCA}_{2}$ activation inhibits PKA activity and subsequently increase BAD levels, which drives apoptosis of neutrophils.

IECs are well-equipped to recognize luminal pathogens by expressing different pattern recognition receptors, including NOD-like receptors (NLRs) in the cytosol and Toll-like receptors (TLRs) on the apical membrane and in endosomes, with the capacity to sample gram-positive and gram-negative infectious bacteria $(65,66)$. Additionally, various immune cells, including intraepithelial $\gamma \delta$-T cells and specialized mucosal macrophages, reside intercalated in the IEC layer, and function to sample pathogens from the lumen (67). IECs also express multimeric protein complexes known as inflammasomes that are important for intestinal immune homeostasis, inflammation, and tumorigenesis. Ligand stimulation of $\mathrm{HCA}_{2}$ expression is associated with increased NLRP3 inflammasome activation, which processes the proIL-18 into IL-18, an anti-inflammatory cytokine which is critical in regulating mucosal immunity and epithelial integrity (46) (Figure 2). Recent studies demonstrate that mice deficient in IL-18 have increased pathogenesis of colitis and colon cancer, and dysregulation of IL- $1 \beta$ expression exacerbates IBD $(48,68)$.

Immune cells are found in intestinal epithelium (intraepithelial lymphocytes) as well as in organized lymphoid tissues/organs, such as the Peyer's Patches (PPs) and mesenteric lymph nodes (MLNs). Substantial amounts of scattered innate and adaptive effector immune cells are also widely distributed in the lamina propria, which is a loosely packed connective tissue layer underlying the IEC layer (69-71) (Figure 2). Collectively, the lamina propria and IECs form 


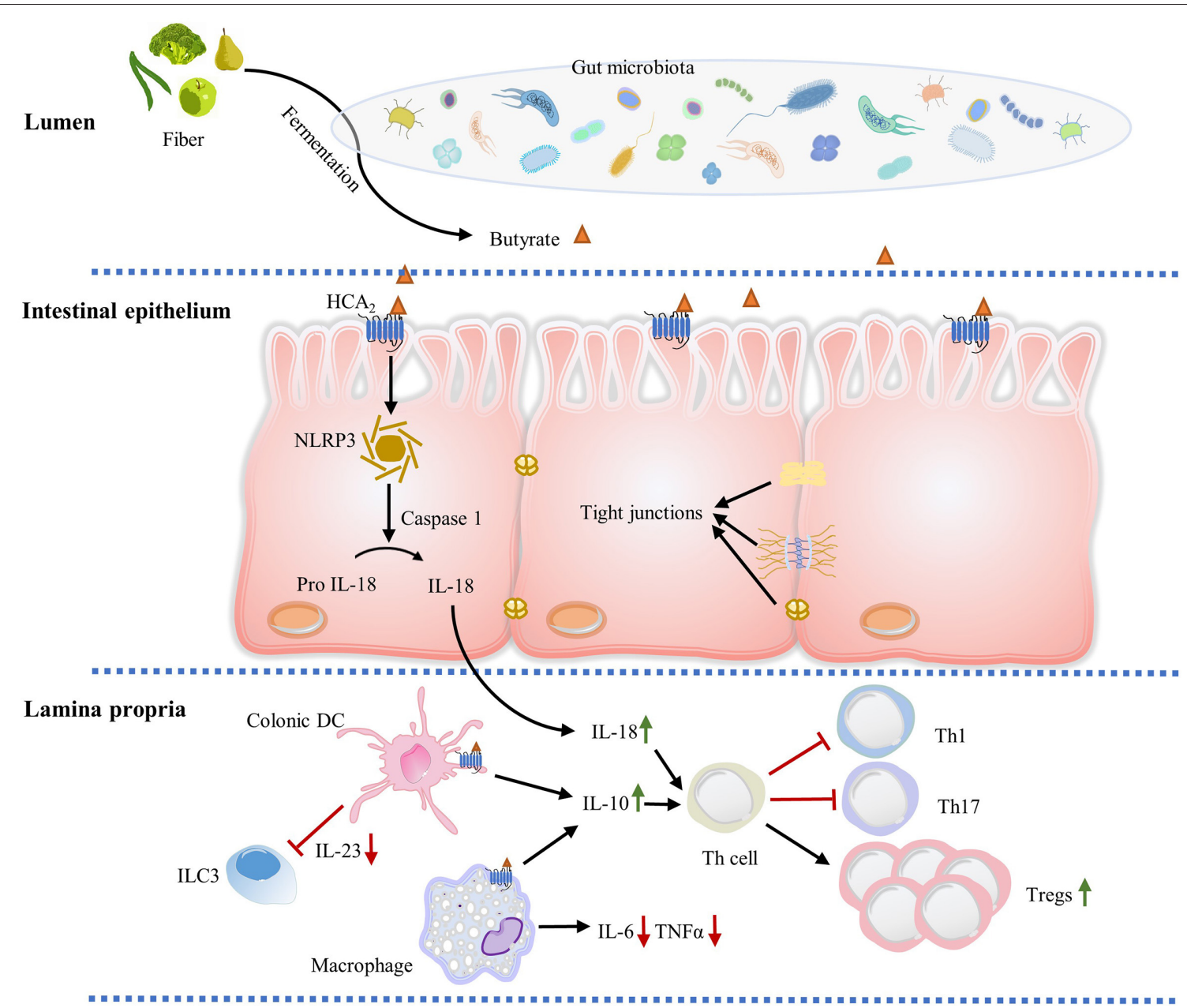

\section{Muscularis mucosa}

FIGURE 2 | $\mathrm{HCA}_{2}$ regulates gut immune homeostasis. Butyrate produced by gut microbiota fermentation activates $\mathrm{HCA}_{2}$ expressed on IECs, macrophages, and dendritic cells. In IECs, $\mathrm{HCA}_{2}$ stimulation is associated with increased inflammasome activation, which processes pro-IL-18 into mature IL-18, which is critical in regulating mucosal immunity and epithelial integrity. IL-18 and ligand induced anti-inflammatory IL-10 (from intestinal macrophages and dendritic cells) promote naïve T cells differentiation and proliferation into immunomodulator Treg cells, which protect intestine from inflammation and colitis associated cancer. IL-18 and IL-10 also decrease the proinflammatory Th1 and Th17 cell number. In addition, $\mathrm{HCA}_{2}$ decreases proinflammatory cytokine IL-6 and TNF- $\alpha$ expression in intestinal macrophages and inhibits dendritic cell-induced IL-23 production to suppress ILC3-associated colonic inflammation.

a unique immunological compartment which contains the largest population of immune cells in the body, as well as supply the nerve, blood and lymph drainage for the entire mucosa (71). The lamina propria contains lymphocytes and numerous innate immune system-related cell populations, including eosinophils, macrophages, DCs, immunoglobulin (Ig) A secreting plasma cells, mast cells and innate lymphoid cells (ILCs) (71-73) (Figure 2). ILCs are a family of three innate effector cells (ILC1, ILC2, and ILC3) that are critical modulators of mucosal immunity (74). Particularly, ILC3 is implicated in innate intestinal inflammation though production of IFN- $\gamma$, IL-17, and IL-22 under induction by IL-1 $\beta$ and IL-23 (75). Depletion of ILC3 abrogates innate colitis, suggesting ILC3 is responsible for the intestinal pathogenesis (75). Bhatt et al. showed that $\mathrm{HCA}_{2}$ signaling limits IL-23 production by DCs, which further suppresses ILC3-mediated colonic inflammation (76) (Figure 2). Activation of $\mathrm{HCA}_{2}$ expressed on immune cells in colon lamina propria also modulates the frequency and number of Treg cells and IL-10 producing T cells (34) (Figure 2).

The gut microbiota is considered a commensal metabolic organ with critical roles in energy salvaging and nutrient absorption. It also functions in systemic immunity regulation and protection of the colonized host by eliminating pathogenic bacteria (77). Tan et al. compared fecal microbiota composition between WT and $\mathrm{HCA}_{2}{ }^{-/}$mice fed a high-fiber diet, and determined that loss of $\mathrm{HCA}_{2}$ alters microbiota composition dramatically (57). Specifically, $\mathrm{HCA}_{2}{ }^{-/}$mice show an increase 
of Verrucomicrobiae, Alphaproteobacteria, and Bacilli, and a decrease of Bacteroidia (57). Germ-free animals show extensive impaired maturation of isolated lymphoid follicles, PPs and MLNs, and are also defective in antibody production and cytokine secretion compared to conventional animals (78). The status of germ-free animals converts after colonization with normal gut microbiota, suggesting a dynamic relationship between the commensal organism and host immune system. Gut microbiota also plays an irreplaceable role in the regulation of host intestinal gene expression with around 700 genes altered remarkably in mice under germ-free conditions. Among them, the expression of $\mathrm{Hca}_{2}$ is reduced significantly in the ileum and colon under germ-free conditions, which is restored to normal levels after introduction of gut bacteria (35).

When the balance of gut microbiota ecosystems is disturbed (dysbiosis), tight junction barrier is compromised. Antigens, toxins and microorganisms can pass through the epithelium and trigger the immune response. Intestinal dysbiosis is commonly associated with a series of intestinal and extraintestinal pathological disorders, including obesity, diabetes mellitus, multisystem organ failure, allergy, asthma, colitisassociated cancer and IBD $(77,79)$. Specifically, IBD patients shift their gut microbiota composition to an enrichment of Desulfovibrio, Enterobacteriaceae, Ruminococcus gnavus, and depletion of Akkermansia Faecalibacterium prausnitzii, and Lachnospiraceae (80).

Multiple evidence suggests that the composition of the intestinal microbiota can be altered by diet within hours to days, leading to aberrant immune responses (81-83). Extensive studies have demonstrated that the structure and function of the gut microbiota rapidly shifts and intestinal atrophy and low-grade inflammation occur under Western diets conditions within 1 day (84-89). Nevertheless, this influence is largely eliminated by manipulating the dietary fiber content in Western diets, allowing for protection against microbiota depletion, amelioration of the inflammation and restoration of colon length $(84,88)$. These beneficial aspects of fiber are largely attributed to bacterial fermentation products (SCFAs), including acetate, propionate and butyrate. SCFAs are sensed by specific immunomodulating receptors, including $\mathrm{HCA}_{2}, \mathrm{GPR} 41$, and GPR43, which are involved in intestinal immunoactivity, intestinal motility regulation and cytokine secretion (90).

Among the SCFAs, butyrate/ $\mathrm{HCA}_{2}$-mediated signaling has received the most attention for its effects on intestinal homeostasis and may provide an important molecular link between gut bacteria and the host (91-94). Numerous studies have confirmed that antibiotic treatment causes gut microbiota dysbiosis by perturbing intestinal immune regulation, evidenced by a reduction in Treg cell numbers within the colon $(95,96)$. Niacin and $\mathrm{HCA}_{2}$ agonist supplementation efficiently rescues Treg cell depletion in antibiotic-treated WT mice, but this effect is nullified in $\mathrm{HCA}_{2}{ }^{-/-}$mice (34). $\mathrm{HCA}_{2}{ }^{-/}$mice also show an inflammatory intestinal phenotype and enhanced susceptibility to azoxymethane (AOM) + dextran sulfate sodium (DSS)induced colitis-associated colon cancer (34). Clinically, patients with ulcerative colitis and colitis-associated cancer suffer a remarkable depletion in the total amount of butyrate-producing bacteria in colon $(97,98)$, while irrigating the colon with butyrate significantly suppresses intestinal inflammation during ulcerative colitis (99). Hence, $\mathrm{HCA}_{2}$ is a critical link in the network of diet, microbiota, immune cells, and host cells which are necessary for the maintenance of intestinal homeostasis.

\section{ROLE OF HCA 2 IN INTESTINAL INFLAMMATION}

The role of $\mathrm{HCA}_{2}$ in regulating intestinal immunological response and inflammation is multifaceted. Singh et al. found that the colons of mice lacking $\mathrm{HCA}_{2}$ present a unique status of $\mathrm{CD}^{+} \mathrm{T}$ cells, also known as $\mathrm{T}$ helper cells (Th cells) (34). These cells play an important role in immune regulation, where they mediate the activation of other immune cells though the release of various cytokines. Among the $\mathrm{CD}^{+} \mathrm{T}$ cells, Tregs express the transcription factor Forkhead box protein P3 (Foxp3), which is capable of potently suppressing immune responses. In colonic lamina propria of $\mathrm{HCA}_{2}{ }^{-/}$mice, the amount of Foxp3 $3^{+} /$Treg cells among $\mathrm{CD}^{+} \mathrm{T}$ cells and antiinflammatory IL-10 producing $\mathrm{CD} 4^{+} \mathrm{T}$ cells is significantly less than WT mice, while the frequency and number of $\mathrm{CD}^{+}{ }^{+} \mathrm{T}$ cells producing the inflammatory cytokine IL-17 are increased (34). In contrast, a similar fraction of those cells distribute in splenic T cells from both WT and $\mathrm{HCA}_{2}{ }^{-/-}$mice, suggesting that only the colon $\mathrm{CD}^{+} \mathrm{T}$ cells are specifically influenced by a lack of $\mathrm{HCA}_{2}{ }^{-/-}$(34). Singh et al. reasoned that this proinflammatory phenotype of the $\mathrm{HCA}_{2}{ }^{-/}$mice colon is dependent on colonic DCs and macrophages, since they both express $\mathrm{HCA}_{2}$ and are critical inducers of naive $\mathrm{T}$ cell differentiation $(100,101)$. They addressed this by testing the ability of colonic DCs and macrophages from both WT and $\mathrm{HCA}_{2}-/-$ mice to induce differentiation of naive $\mathrm{CD} 4^{+}$ $\mathrm{T}$ cells. As expected, $\mathrm{HCA}_{2}{ }^{-/}$colonic DCs and macrophages are defective in expression of retinaldehyde dehydrogenase 1 (RALDH1) and immunosuppressive cytokine IL-10, and express more proinflammatory cytokine IL-6 compared to WT DCs and macrophages. This change in expression leads naive $\mathrm{CD}^{+}{ }^{+} \mathrm{T}$ cells to differentiate into proinflammatory Th17 cells, but not Treg cells and IL-10-producing $\mathrm{CD}^{+} \mathrm{T}$ cells (34). Likewise, $\mathrm{HCA}_{2}{ }^{-/-}$is necessary to maintain normal anti-inflammatory IL-18 levels, as both mRNA and protein expression of IL-18 are significantly decreased in IECs of $\mathrm{HCA}_{2}{ }^{-/}$mice (34). Consistent with this evidence, Singh et al. also demonstrated that niacin treatment restored colonic Treg cell numbers in antibiotic-treated WT mice, and butyrate and niacin induced IL-10 and RALDH1 expression and promoted naïve $\mathrm{T}$ cells differentiation into Treg cells in macrophages and DCs in an $\mathrm{HCA}_{2}$-dependent manner (34) (Figure 2). In addition, butyrate and niacin increased expression of IL-18 in colonic epithelium of WT mice but not $\mathrm{HCA}_{2}{ }^{-/-}$mice (34).

Bhatt et al. recently described another anti-inflammatory effect of $\mathrm{HCA}_{2}$ in restraining microbiota-induced IL-23 
production to suppress ILC3-associated colonic inflammation (76). To diminish the influence of the adaptive immune system, they bred $\mathrm{HCA}_{2}{ }^{-/-}$mice with recombination activating gene 1 (RAG1) deficient mice [no mature $\mathrm{B}$ and $\mathrm{T}$ lymphocytes (102)] to generate $\mathrm{HCA}_{2}{ }^{-/-} \mathrm{Rag}^{-/-}$mice. $\mathrm{HCA}_{2}{ }^{-/-} \mathrm{Rag} 1^{-/-}$mice spontaneously develop rectal prolapse and exhibit immune cell infiltration of the intestinal lamina propria, which is not seen in $\mathrm{Rag} 1^{-/-}$mice under the same conditions (76). In addition, colons of $\mathrm{HCA}_{2}{ }^{-/-} \mathrm{Rag}^{-/-}$mice are larger and hypercellular, over proliferative with hyperchromatic and pseudostratified nuclei and have significantly elevated number of neutrophils compared to $\mathrm{Rag}^{-/-}$mice (76). As a result, $\mathrm{HCA}_{2}{ }^{-/-} \mathrm{Rag}^{-/-}$ mice have significantly higher colitis scores for colons and cecum compared to Rag1 $1^{-/-}$mice (76). Importantly, $\mathrm{HCA}_{2}{ }^{-/-}$ Rag1 ${ }^{-/-}$mice have significantly increased numbers of ILC3 in the colonic lamina propria, mesenteric lymph nodes and small intestine, leading to a markedly higher frequency of IL-17 in the colonic lamina propria and mesenteric lymph nodes (76). Niacin significantly decreases IL-23 production by colonic DCs and the numbers of ILC3 in Rag1 ${ }^{-/-}$mice, but fails to do so in $\mathrm{HCA}_{2}{ }^{-/-}$ $\mathrm{Rag} 1^{-/-}$mice (76). Furthermore, $\mathrm{HCA}_{2}{ }^{-/-} \mathrm{Rag}^{-/-}$mice present signs of ongoing adenomatous transformation in the cecum and colonize a higher portion of IBD associated bacteria including Bacteroidaceae, Porphyromonadaceae, Prevotellaceae, Streptococcaceae, Christensenellaceae, Mogibacteriaceae, Enterobacteriaceae, and Mycoplasmataceae. Depletion of gut microbiota by antibiotics alleviates colonic inflammation by decreasing production of IL-23 and induction of ILC3 in $\mathrm{HCA}_{2}{ }^{-/-} \mathrm{Rag} 1^{-/-}$mice (76).

Further detailed studies on the role of $\mathrm{HCA}_{2}$ in DSSinduced colitis treatment demonstrate that $\mathrm{HCA}_{2}{ }^{-/-}$mice are highly susceptible to colitis development, with all experimental animals succumbing to death 10 days after DSS administration (3). In contrast, WT counterparts all survive through the entirety of the DSS treatment (34). Sodium butyrate markedly reduces inflammation and improves IECs barrier integrity by activating $\mathrm{HCA}_{2}$ signaling and suppressing the AKT-NF$\kappa B$ p65 signaling pathway in 2,4,6-trinitrobenzene sulfonic acid (TNBS)-induced colitis, a model that resembles Crohn's disease $(51,52)$. In a similar study, a sodium butyratecontaining diet attenuates diarrhea symptoms and facilitates tight junction protein expression in the colon of piglets by acting on Akt signaling pathway in an $\mathrm{HCA}_{2}$-dependent manner (103). Another source of butyrate, tributyrin, is a chemically stable structured lipid that could be administered orally (104). Tributyrin supplementation prevents mice from chronic and acute ethanol-induced gut injury by improving gut barrier function (occludin, ZO-1) and increasing the expression of $\mathrm{HCA}_{2}$ in both ileum and proximal colon (105). In accordance with this, niacin administration attenuates iodoacetamideinduced colitis by a reduction in colon weight and colonic myeloperoxidase activity (a hallmark of colonic inflammation), and restores normal levels of colonic IL-10, tumor necrosis factor alpha (TNF- $\alpha$ ), angiostatin and endostatin in a rat model (106). This beneficial effect of niacin is largely abolished by mepenzolate bromide, a $\mathrm{HCA}_{2}$ receptor blocker, indicating niacin/ $\mathrm{HCA}_{2}$ signaling ameliorates iodoacetamide-induced colitis (106). In addition to it oral pharmacologic activity, niacin is also a microbial-derived metabolite, produced by specific gut microbiota, including Lactobacillus acidophilus, Bacteroides fragilis, Prevotella copri, Fusobacterium varium, Clostridium difficile, Bifidobacterium infantis, and Ruminococcus lactaris $(76,107,108)$. Niacin deficiency is associated with intestinal inflammation and diarrhea (76).

Overall, these reports provide compelling evidence that $\mathrm{HCA}_{2}$ signaling modulates immune cells to inhibit production of several inflammatory cytokines, pathways, and enzymes, leading to the suppression of experimental models of colitis.

\section{ROLE OF HCA 2 IN COLON CANCER}

$\mathrm{HCA}_{2}$ not only plays a critical role in the suppression of intestinal inflammation, but also has a significant effect on colonic cancer development and progression. Expression of $\mathrm{HCA}_{2}$ is silenced in colon cancer cell lines, and in both mice and humans with colon cancer (24). The tumor-associated silencing of $\mathrm{HCA}_{2}$ involves DNA methyltransferase 1 (DNMT1)mediated DNA methylation (24) (Figure 3A). Reexpression of $\mathrm{HCA}_{2}$ in cancer cell lines induces apoptosis by inhibiting $\mathrm{B}-$ cell lymphoma (Bcl)-2, B-cell lymphoma-extra-large (Bcl-xL), cyclin D1 and NF- $\mathrm{KB}$ activity and upregulating the death receptor pathway in a ligand-dependent manner (Figure 3B). Butyrate is also an inhibitor of histone deacetylases, but this $\mathrm{HCA}_{2}$-mediated effort in colon cancer cells does not involve repressing histone deacetylation (24). Strikingly, Bardhan et al. discovered that IFN- $\gamma$ reverses DNA methylation-mediated $\mathrm{HCA}_{2}$ silencing without altering the methylation status of the $\mathrm{HCA}_{2}$ promoter in colon carcinoma cells (109). Signal transducer and activator of transcription 1 (STAT1) is rapidly activated by IFN- $\gamma$ and binds to the $\mathrm{p} 300$ promoter to activate $\mathrm{p} 300$ transcription. p300 is a histone acetyltransferase and a master transcriptional mediator in mammalian cells, resulting in a permissive chromatin conformation at the $\mathrm{HCA}_{2}$ promoter to allow STAT1 to activate $\mathrm{HCA}_{2}$ transcription despite DNA methylation (109) (Figure 3B).

Consistently, $\mathrm{HCA}_{2}{ }^{-1-}$ mice are more susceptible to the development of colon cancer $(34,46,106,110)$. In mouse models of inflammation-associated colon cancer caused by AOM and DSS, colons of $\mathrm{HCA}_{2}{ }^{-/-}$mice shrink with highly increased myeloperoxidase activity, upregulated expression of colon cancer-promoting genes such as cyclin-D1, cyclin-B1, and cyclin-dependent kinase 1, decreased tight junction proteins expression and decreased expression of genes that inhibit colitis and colon carcinogenesis, such as transforming growth factor beta $(T g f b) 1, T g f b 2$, Solute Carrier Family 5 Member 8 (Slc5a8), MutS Homolog (Msh)2, and Msh3 (34) (Figure 3C). In addition, $\mathrm{HCA}_{2}{ }^{-1-}$ mice exhibit a severe impairment of IL-10 and IL-18 production when compared to WT counterparts (34, 111) (Figure 3C). Histologically, crypt and epithelium structure damage, mucosa ulcerations and large amount of immune cell infiltration is observed in colons of AOM+DSS treated 


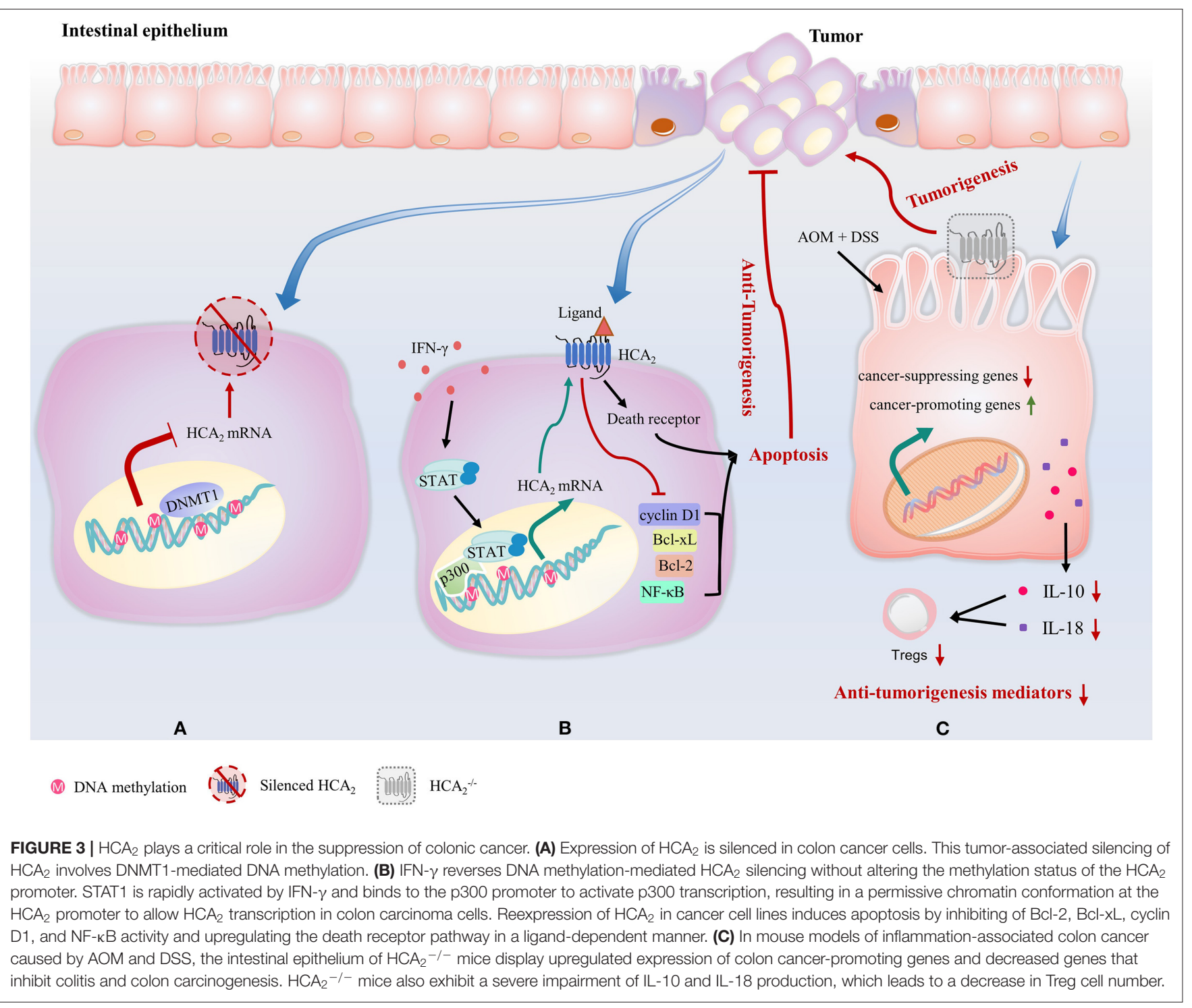

$\mathrm{HCA}_{2}{ }^{-/-}$mice group, indicating epithelial barrier breakdown (34). Systemically, levels of both colonic and serum cytokines that promote colonic inflammation and carcinogenesis such as amyloid A, chemokine (C-X-C motif) ligand (CXCL) 1, C-C motif chemokine ligand (CCL) 2, IL-1 $\beta$, IL-6, and IL-17 are all elevated. At the end of the AOM+DSS treatment regime, $\mathrm{HCA}_{2}{ }^{-/}$mice demonstrate anemia and increased number of large polyps on colon (34). Remarkably, niacin administration suppresses colon tumor development in antibiotic-treated microbiota-depleted WT mice (34). However, it also promotes colitis-associated cancer in $\mathrm{HCA}_{2}{ }^{-/-}$mice, which is associated with an expansion of bacteria in Prevotellaceae family and TM7 phylum (34), suggesting microbiota/niacin protective effect is $\mathrm{HCA}_{2}$-dependent. In the same report, Singh et al. manipulated another mouse model of intestinal carcinogenesis, $\mathrm{Apc}^{\mathrm{Min} /+}$, in which multiple intestinal neoplasia (Min) is a mutant allele of the murine adenomatous polyposis coli $(A p c)$ locus (110). Apc ${ }^{\mathrm{Min} /+}$ mice show significantly enlarged colonic polyp numbers, which were rescued by niacin treatment. However, niacin was not able to decrease the development of colonic polyps in $\mathrm{HCA}_{2}{ }^{-/-} \mathrm{Apc}^{\mathrm{Min} /+}$ (34).

Taken together, these data demonstrate that $\mathrm{HCA}_{2}$ mediates cancer development and progression by promoting intestine mucosal immunity and decreasing cancer-promoting genes.

\section{ANTI-INFLAMMATORY EFFECTS OF $\mathrm{HCA}_{2}$ IN OTHER DISEASES}

$\mathrm{HCA}_{2}$ signaling plays an essential role in preventing and reducing inflammation in the intestine. In addition, $\mathrm{HCA}_{2}$ has also been associated with anti-inflammatory effects in numerous disease states. In particular, various studies report that activation of $\mathrm{HCA}_{2}$ reduces inflammation in atherosclerosis (36), diabetes mellitus (25), diabetic retinopathy (31), neurodegenerative diseases (37, 38), sepsis (39), mammary cancer (40) and 
pancreatitis (41). Activation of $\mathrm{HCA}_{2}$ on immune cells in the vasculature by niacin reduces the progression of atherosclerosis and suppresses macrophage recruitment to atherosclerotic plaques (36). Chronic activation of $\mathrm{HCA}_{2}$ by niacin increases serum adiponectin in obese men with metabolic syndrome, suggesting a role in diabetes mellitus and obesity $(112,113)$. Additionally, in pancreatic islets of diabetic $\mathrm{db} / \mathrm{db}$ mice as well as in type 2 diabetic (T2D) patients, $\mathrm{HCA}_{2}$ expression is decreased (114). Administration of GSK256073, a $\mathrm{HCA}_{2}$ agonist, notably reduced serum glucose and non-esterified fatty acids without inducing the niacin-associated side effect of cutaneous flushing in diabetic patients (25). In retinal pigmented epithelial cells, niacinmediated activation of $\mathrm{HCA}_{2}$ suppresses TNF- $\alpha$-induced NF- $\kappa \mathrm{B}$ activation and IL- 6 and monocyte chemoattractant protein-1 (MCP-1) secretion (31). $\mathrm{HCA}_{2}$ ligands have been also reported to attenuate inflammation in neurodegenerative diseases such as Parkinson's disease (115), Huntington's disease (38), Alzheimer's disease (116), multiple sclerosis (37), ischemic stroke (117) and traumatic brain injury (118), although, the mechanisms behind many of these beneficial effects have yet to be fully elucidated. In sepsis, niacin attenuated kidney and lung inflammation by decreasing NF- $\kappa \mathrm{B}$ activation and subsequently decreasing inflammatory cytokines $(39,119,120)$. As was the case in colon cancer, $\mathrm{HCA}_{2}$ functions as a tumor suppressor in mammary cancer via inhibition of genes involved in cell survival and anti-apoptotic pathways in human breast cancer cell lines (40). In pancreatitis, $\beta$-OHB supplementation inhibits macrophage NF- $\kappa \mathrm{B}$ activation in an $\mathrm{HCA}_{2}$-dependent manner, and limits sterile inflammation (41). Moreover, $\mathrm{HCA}_{2}$ plays an antiviral role in reducing the Zika virus replication. $\mathrm{HCA}_{2}$ expression is significantly induced by Zika virus infection, while depletion of $\mathrm{HCA}_{2}$ resulted in significant increase of Zika virus RNA levels and viral yields, indicating that $\mathrm{HCA}_{2}$ can serve as a restriction factor for Zika virus and providing a potential target for anti- Zika virus therapeutic (121).

\section{REFERENCES}

1. Choct M. Managing gut health through nutrition. Br Poult Sci. (2009) 50:9-15. doi: 10.1080/00071660802538632

2. Abedi V, Lu P, Hontecillas R, Verma M, Vess G, Philipson CW, et al. Phase III placebo-controlled, randomized clinical trial with synthetic Crohn's disease patients to evaluate treatment response. Computational Modeling-Based Discovery of Novel Classes of AntiInflammatory Drugs that Target Lanthionine Synthetase C-Like Protein. Emerg Trends Comput Biol Bioinform Syst Biol Syst Appl. (2015) 2:169. doi: 10.1016/b978-0-12-804203-8.00028-6

3. Maloy KJ, Powrie F. Intestinal homeostasis and its breakdown in inflammatory bowel disease. Nature. (2011) 474:298-306. doi: 10.1038/nature10208

4. Kaser A, Lee A-H, Franke A, Glickman JN, Zeissig S, Tilg H, et al. XBP1 links ER stress to intestinal inflammation and confers genetic risk for human inflammatory bowel disease. Cell. (2008) 134:743-56. doi: 10.1016/j.cell.2008.07.021

5. Stokkers P, Hommes D. New cytokine therapeutics for inflammatory bowel disease. Cytokine. (2004) 28:167-73. doi: 10.1016/j.cyto.2004.07.012

6. Guan Q, Zhang J. Recent advances: the imbalance of cytokines in the pathogenesis of inflammatory bowel disease. Mediat Inflamm. (2017) 2017:4810258. doi: $10.1155 / 2017 / 4810258$

\section{CONCLUSION}

There is mounting evidence summarized in this review that $\mathrm{HCA}_{2}$ plays an important role in modulating inflammation and carcinogenesis in the intestine. Ligands for the $\mathrm{HCA}_{2}$ receptor mediate a wide variety of inflammation-suppressing signaling events. NF- $\kappa$, NLRP3 and prostaglandins $\mathrm{PGD}_{2}$ and $\mathrm{PGE}_{2}$ have all been implicated as downstream targets of the $\mathrm{HCA}_{2}$ receptor, suggesting activation of one pathway may have beneficial or undesirable effects that are tissuedependent. Therefore, tissue-specific, pharmacologic ligands which trigger bias signaling cascades, and therefore minimize less desirable downstream effects, are required. In addition, these pathways interweave the process of inflammatory and metabolic disorders through $\mathrm{HCA}_{2}$. Thus, this interplay of gut microbiota, $\mathrm{HCA}_{2}$ signaling and immune responses is a double-edged sword of inducing inflamed intestinal diseases or colon cancer and promoting intestinal homeostasis.

\section{AUTHOR CONTRIBUTIONS}

ZL was primarily responsible for researching and writing the manuscript (including the generation of figures). KM was responsible for writing specific sections and reviewing the manuscript. RJ proposed the topic of the review and supervised the writing and review of the manuscript. All authors contributed to the article and approved the submitted version.

\section{FUNDING}

This work was supported by Auburn University, Intramural Grant Program and the Boshell Diabetes and Metabolic Diseases Research Program.

7. Feagins LA, Souza RF, Spechler SJ. Carcinogenesis in IBD: potential targets for the prevention of colorectal cancer. Nat Rev Gastroenterol Hepatol. (2009) 6:297-305. doi: 10.1038/nrgastro.2009.44

8. Kinugasa T, Akagi Y. Status of colitis-associated cancer in ulcerative colitis. World J Gastrointest Oncol. (2016) 8:351. doi: 10.4251/wjgo.v8.i4.351

9. Sairenji T, Collins KL, Evans DV. An update on inflammatory bowel disease. Prim Care. (2017) 44:673-692. doi: 10.1016/j.pop.2017.07.010

10. Dahlhamer JM, Zammitti EP, Ward BW, Wheaton AG, Croft JB. Prevalence of inflammatory bowel disease among adults aged $\geq 18$ years-United States, 2015. Morbid Mortal Week Rep. (2016) 65:1166-9. doi: 10.15585/mmwr.mm6542a3

11. Monteleone G, Fina D, Caruso R, Pallone F. New mediators of immunity and inflammation in inflammatory bowel disease. Curr Opin Gastroenterol. (2006) 22:361-4. doi: 10.1097/01.mog.0000231808.10773.8e

12. Guan Q. A comprehensive review and update on the pathogenesis of inflammatory bowel disease. J Immunol Res. (2019) 2019:7247238. doi: $10.1155 / 2019 / 7247238$

13. Kraehenbuhl J-P, Neutra MR. Molecular and cellular basis of immune protection of mucosal surfaces. Physiol Rev. (1992) 72:853-79. doi: 10.1152/physrev.1992.72.4.853

14. Nomura H, Nielsen BW, Matsushima K. Molecular cloning of cDNAs encoding a LD78 receptor and putative leukocyte chemotactic peptide receptors. Int Immunol. (1993) 5:1239-49. doi: 10.1093/intimm/5.10.1239 
15. Gille A, Bodor ET, Ahmed K, Offermanns S. Nicotinic acid: pharmacological effects and mechanisms of action. Annu Rev Pharmacol Toxicol. (2008) 48:79-106. doi: 10.1146/annurev.pharmtox.48.113006.094746

16. Schaub A, Fütterer A, Pfeffer K. PUMA-G, an IFN- $\gamma$-inducible gene in macrophages is a novel member of the seven transmembrane spanning receptor superfamily. Eur J Immunol. (2001) 31:3714-25. doi: 10.1002/1521-4141(200112)31:12<3714::AID-IMMU3714>3.0.CO;2-1

17. Soga T, Kamohara M, Takasaki J, Matsumoto S-I, Saito T, Ohishi T, et al. Molecular identification of nicotinic acid receptor. Biochem Biophys Res Commun. (2003) 303:364-9. doi: 10.1016/S0006-291X(03)00342-5

18. Tunaru S, Kero J, Schaub A, Wufka C, Blaukat A, Pfeffer K, et al. PUMAG and HM74 are receptors for nicotinic acid and mediate its anti-lipolytic effect. Nat Med. (2003) 9:352. doi: 10.1038/nm824

19. Wise A, Foord SM, Fraser NJ, Barnes AA, Elshourbagy N, Eilert M, et al. Molecular identification of high and low affinity receptors for nicotinic acid. J Biol Chem. (2003) 278:9869-74. doi: 10.1074/jbc.M210695200

20. Benyó Z, Gille A, Kero J, Csiky M, Suchánková MC, Nüsing RM, et al. GPR109A (PUMA-G/HM74A) mediates nicotinic acid-induced flushing. J Clin Investig. (2005) 115:3634-40. doi: 10.1172/JCI23626

21. Hanson J, Gille A, Zwykiel S, Lukasova M, Clausen BE, Ahmed K, et al. Nicotinic acid-and monomethyl fumarate-induced flushing involves GPR109A expressed by keratinocytes and COX-2-dependent prostanoid formation in mice. J Clin Investig. (2010) 120:2910-9. doi: 10.1172/JCI42273

22. Taggart AK, Kero J, Gan X, Cai T-Q, Cheng K, Ippolito M, et al. (D)- $\beta$ hydroxybutyrate inhibits adipocyte lipolysis via the nicotinic acid receptor PUMA-G. J Biol Chem. (2005) 280:26649-52. doi: 10.1074/jbc.C5002 13200

23. Offermanns S, Colletti SL, Lovenberg TW, Semple G, Wise A, IJzerman AP. International Union of Basic and Clinical Pharmacology. LXXXII: nomenclature and classification of hydroxy-carboxylic acid receptors (GPR81, GPR109A, and GPR109B). Pharmacol Rev. (2011) 63:269-90. doi: $10.1124 /$ pr.110.003301

24. Thangaraju M, Cresci GA, Liu K, Ananth S, Gnanaprakasam JP, Browning $\mathrm{DD}$, et al. GPR109A is a G-protein-coupled receptor for the bacterial fermentation product butyrate and functions as a tumor suppressor in colon. Cancer Res. (2009) 69:2826-32. doi: 10.1158/0008-5472.CAN08-4466

25. Dobbins R, Shearn S, Byerly R, Gao F, Mahar K, Napolitano A, et al. GSK256073, a selective agonist of G-protein coupled receptor 109A (GPR109A) reduces serum glucose in subjects with type 2 diabetes mellitus. Diabetes Obes Metab. (2013) 15:1013-21. doi: 10.1111/dom. 12132

26. Ahmed K, Tunaru S, Offermanns S. GPR109A, GPR109B and GPR81, a family of hydroxy-carboxylic acid receptors. Trends Pharmacol Sci. (2009) 30:557-62. doi: 10.1016/j.tips.2009.09.001

27. Semple G, Skinner PJ, Gharbaoui T, Shin Y-J, Jung J-K, Cherrier MC, et al. 3-(1 H-tetrazol-5-yl)-1, 4, 5, 6-tetrahydro-cyclopentapyrazole (MK-0354): a partial agonist of the nicotinic acid receptor, G-protein coupled receptor 109 a, with antilipolytic but no vasodilatory activity in mice. J Med Chem. (2008) 51:5101-8. doi: 10.1021/jm800258p

28. Maciejewski-Lenoir D, Richman JG, Hakak Y, Gaidarov I, Behan DP, Connolly DT. Langerhans cells release prostaglandin D2 in response to nicotinic acid. J Investig Dermatol. (2006) 126:2637-46. doi: 10.1038/sj.jid.5700586

29. Yousefi S, Cooper PR, Mueck B, Potter SL, Jarai G., cDNA representational difference analysis of human neutrophils stimulated by GM-CSF. Biochem Biophys Res Commun. (2000) 277:401-9. doi: 10.1006/bbrc.2000.3678

30. Shi Y, Lai X, Ye L, Chen K, Cao Z, Gong W, et al. Activated niacin receptor HCA2 inhibits chemoattractant-mediated macrophage migration via $\mathrm{G} \beta \gamma / \mathrm{PKC} / \mathrm{ERK} 1 / 2$ pathway and heterologous receptor desensitization. Sci Rep. (2017) 7:42279. doi: 10.1038/srep42279

31. Gambhir D, Ananth S, Veeranan-Karmegam R, Elangovan S, Hester S, Jennings E, et al. GPR109A as an anti-inflammatory receptor in retinal pigment epithelial cells and its relevance to diabetic retinopathy. Investig Ophthalmol Vis Sci. (2012) 53:2208-17. doi: 10.1167/iovs.11-8447

32. Graff E, Norris O, Sandey M, Kemppainen R, Judd R. Characterization of the hydroxycarboxylic acid receptor 2 in cats. Domest Anim Endocrinol. (2015) 53:88-94. doi: 10.1016/j.domaniend.2015.06.001
33. Ge H, Weiszmann J, Reagan JD, Gupte J, Baribault H, Gyuris T, et al. Elucidation of signaling and functional activities of an orphan GPCR, GPR81. J Lipid Res. (2008) 49:797-803. doi: 10.1194/jlr.M700513-JLR200

34. Singh N, Gurav A, Sivaprakasam S, Brady E, Padia R, Shi H, et al. Activation of Gpr109a, receptor for niacin and the commensal metabolite butyrate, suppresses colonic inflammation and carcinogenesis. Immunity. (2014) 40:128-39. doi: 10.1016/j.immuni.2013.12.007

35. Cresci GA, Thangaraju M, Mellinger JD, Liu K, Ganapathy V. Colonic gene expression in conventional and germ-free mice with a focus on the butyrate receptor GPR109A and the butyrate transporter SLC5A8. J Gastrointest Surg. (2010) 14:449-61. doi: 10.1007/s11605-009-1045-x

36. Lukasova M, Malaval C, Gille A, Kero J, Offermanns S. Nicotinic acid inhibits progression of atherosclerosis in mice through its receptor GPR109A expressed by immune cells. J Clin Investig. (2011) 121:1163-73. doi: 10.1172/JCI41651

37. Hao J, Liu R, Turner G, Shi F-D, Rho JM. Inflammation-mediated memory dysfunction and effects of a ketogenic diet in a murine model of multiple sclerosis. PLoS ONE. (2012) 7:e35476. doi: 10.1371/journal.pone.0035476

38. Lim S, Chesser AS, Grima JC, Rappold PM, Blum D, Przedborski S, et al. $\mathrm{D}$ - $\beta$-hydroxybutyrate is protective in mouse models of Huntington's disease. PLoS ONE. (2011) 6:e24620. doi: 10.1371/journal.pone.0024620

39. Kwon WY, Suh GJ, Kim KS, Kwak YH. Niacin attenuates lung inflammation and improves survival during sepsis by downregulating the nuclear factor-кB pathway. Crit Care Med. (2011) 39:328-34. doi: 10.1097/CCM.0b013e3181feeae4

40. Elangovan S, Pathania R, Ramachandran S, Ananth S, Padia RN, Lan $\mathrm{L}$, et al. The niacin/butyrate receptor GPR109A suppresses mammary tumorigenesis by inhibiting cell survival. Cancer Res. (2014) 74:1166-78. doi: 10.1158/0008-5472.CAN-13-1451

41. Hoque R, Mehal WZ. Inflammasomes in pancreatic physiology and disease. Am J Physiol Gastrointest Liver Physiol. (2015) 308:G643-51. doi: 10.1152/ajpgi.00388.2014

42. Carlson LA, Orö L. The effect of nicotinic acid on the plasma free fatty acids demonstration of a metabolic type of sympathicolysis. Acta Med Scand. (1962) 172:641-5. doi: 10.1111/j.0954-6820.1962.tb07203.x

43. Hanson J, Gille A, Offermanns S. Role of HCA2 (GPR109A) in nicotinic acid and fumaric acid ester-induced effects on the skin. Pharmacol Ther. (2012) 136:1-7. doi: 10.1016/j.pharmthera.2012.06.003

44. Ye L, Cao Z, Lai X, Shi Y, Zhou N. Niacin ameliorates hepatic steatosis by inhibiting de novo lipogenesis via a GPR109A-mediated PKC-ERK1/2AMPK signaling pathway in C57BL/6 mice fed a high-fat diet. J Nutr. (2020) 150:672-84. doi: 10.1093/jn/nxz303

45. Ye L, Cao Z, Lai X, Wang W, Guo Z, Yan L, et al. Niacin fine-tunes energy homeostasis through canonical GPR109A signaling. FASEB J. (2019) 33:4765-79. doi: 10.1096/fj.201801951R

46. Macia L, Tan J, Vieira AT, Leach K, Stanley D, Luong S, et al. Metabolitesensing receptors GPR43 and GPR109A facilitate dietary fibre-induced gut homeostasis through regulation of the inflammasome. Nat Commun. (2015) 6:6734. doi: $10.1038 /$ ncomms 7734

47. Zaki MH, Lamkanfi M, Kanneganti T-D. The Nlrp3 inflammasome: contributions to intestinal homeostasis. Trends Immunol. (2011) 32:171-9. doi: 10.1016/j.it.2011.02.002

48. Rathinam VA, Fitzgerald KA. Inflammasome complexes: emerging mechanisms and effector functions. Cell. (2016) 165:792-800. doi: 10.1016/j.cell.2016.03.046

49. Gautam J, Banskota S, Shah S, Jee JG, Kwon E, Wang Y, et al. 4Hydroxynonenal-induced GPR109A (HCA2 receptor) activation elicits bipolar responses, Gai-mediated anti-inflammatory effects and G $\beta \gamma$-mediated cell death. Br J Pharmacol. (2018) 175:2581-98. doi: 10.1111/bph.14174

50. Offermanns S, Schwaninger M. Nutritional or pharmacological activation of HCA2 ameliorates neuroinflammation. Trends Mol Med. (2015) 21:245-55. doi: 10.1016/j.molmed.2015.02.002

51. Zandi-Nejad K, Takakura A, Jurewicz M, Chandraker AK, Offermanns S, Mount D, et al. The role of HCA2 (GPR109A) in regulating macrophage function. FASEB J. (2013) 27:4366-74. doi: 10.1096/fj.12-223933

52. Fu S-P, Wang J-F, Xue W-J, Liu H-M, Liu B-R, Zeng Y-L, et al. Antiinflammatory effects of BHBA in both in vivo and in vitro Parkinson's disease 
models are mediated by GPR109A-dependent mechanisms. J Neuroinflamm. (2015) 12:1-14. doi: 10.1186/s12974-014-0230-3

53. Fu S-P, Li S-N, Wang J-F, Li Y, Xie S-S, Xue W-J, et al. BHBA suppresses LPSinduced inflammation in BV-2 cells by inhibiting NF- $\mathrm{K}$ B activation. Mediat Inflamm. (2014) 2014:983401. doi: 10.1155/2014/983401

54. Digby JE, Martinez F, Jefferson A, Ruparelia N, Chai J, Wamil M, et al. Antiinflammatory effects of nicotinic acid in human monocytes are mediated by GPR109A dependent mechanisms. Arterioscler Thromb Vasc Biol. (2012) 32:669-76. doi: 10.1161/ATVBAHA.111.241836

55. Vitali, Mingozzi F, Broggi A, Barresi S, Zolezzi F, Bayry J, et al. Migratory, not lymphoid-resident, dendritic cells maintain peripheral self-tolerance and prevent autoimmunity via induction of iTreg cells. Blood. (2012) 120:123745. doi: 10.1182/blood-2011-09-379776

56. Bakdash G, Vogelpoel LT, Van Capel TM, Kapsenberg ML, de Jong EC. Retinoic acid primes human dendritic cells to induce gut-homing, IL-10-producing regulatory T cells. Mucosal Immunol. (2015) 8:265-78. doi: $10.1038 / \mathrm{mi} .2014 .64$

57. Tan J, McKenzie C, Vuillermin PJ, Goverse G, Vinuesa CG, Mebius RE, et al. Dietary fiber and bacterial SCFA enhance oral tolerance and protect against food allergy through diverse cellular pathways. Cell Rep. (2016) 15:2809-24. doi: 10.1016/j.celrep.2016.05.047

58. Kostylina G, Simon D, Fey M, Yousefi S, Simon H-U. Neutrophil apoptosis mediated by nicotinic acid receptors (GPR109A). Cell Death Differ. (2008) 15:134-42. doi: 10.1038/sj.cdd.4402238

59. Arumugam M, Raes J, Pelletier E, Le Paslier D, Yamada T, Mende DR, et al. Enterotypes of the human gut microbiome. Nature. (2011) 473:174-80. doi: 10.1038/nature09944

60. Karaki S-I, Mitsui R, Hayashi H, Kato I, Sugiya H, Iwanaga T, et al. Shortchain fatty acid receptor, GPR43, is expressed by enteroendocrine cells and mucosal mast cells in rat intestine. Cell Tissue Res. (2006) 324:353-60. doi: 10.1007/s00441-005-0140-x

61. Weiser MM. Intestinal epithelial cell surface membrane glycoprotein synthesis I. An indicator of cellular differentiation. J Biol Chem. (1973) 248:2536-41. doi: 10.1016/S0021-9258(19)44141-0

62. Peterson LW, Artis D. Intestinal epithelial cells: regulators of barrier function and immune homeostasis. Nat Rev Immunol. (2014) 14:141-53. doi: $10.1038 /$ nri3608

63. Umar S. Intestinal stem cells. Curr Gastroenterol Rep. (2010) 12:340-8. doi: 10.1007/s11894-010-0130-3

64. Gonzalez-Mariscal L, Betanzos A, Nava P, Jaramillo B. Tight junction proteins. Progr Biophys Mol Biol. (2003) 81:1-44. doi: 10.1016/S0079-6107(02)00037-8

65. Hisamatsu T, Suzuki M, Reinecker H-C, Nadeau WJ, McCormick BA, Podolsky DK. CARD15/NOD2 functions as an antibacterial factor in human intestinal epithelial cells. Gastroenterology. (2003) 124:993-1000. doi: 10.1053/gast.2003.50153

66. Abreu MT. Toll-like receptor signalling in the intestinal epithelium: how bacterial recognition shapes intestinal function. Nat Rev Immunol. (2010) 10:131-44. doi: 10.1038/nri2707

67. Chen Y, Chou K, Fuchs E, Havran WL, Boismenu R. Protection of the intestinal mucosa by intraepithelial $\gamma \delta$ T cells. Proc Natl Acad Sci USA. (2002) 99:14338-43. doi: 10.1073/pnas.212290499

68. Zaki MH, Boyd KL, Vogel P, Kastan MB, Lamkanfi M, Kanneganti TD. The NLRP3 inflammasome protects against loss of epithelial integrity and mortality during experimental colitis. Immunity. (2010) 32:379-91. doi: 10.1016/j.immuni.2010.03.003

69. Niess JH, Brand S, Gu X, Landsman L, Jung S, McCormick BA, et al. CX3CR1-mediated dendritic cell access to the intestinal lumen and bacterial clearance. Science. (2005) 307:254-8. doi: 10.1126/science.1102901

70. Varol C, Vallon-Eberhard A, Elinav E, Aychek T, Shapira Y, Luche H, et al. Intestinal lamina propria dendritic cell subsets have different origin and functions. Immunity. (2009) 31:502-12. doi: 10.1016/j.immuni.2009.06.025

71. Mowat AM, Agace WW. Regional specialization within the intestinal immune system. Nat Rev Immunol. (2014) 14:667-85. doi: 10.1038/nri3738

72. Hooper LV, Macpherson AJ. Immune adaptations that maintain homeostasis with the intestinal microbiota. Nat Rev Immunol. (2010) 10:159-69. doi: $10.1038 /$ nri2710
73. Bernink JH, Krabbendam L, Germar K, de Jong E, Gronke K, Kofoed-Nielsen $\mathrm{M}$, et al. Interleukin-12 and-23 control plasticity of CD127+ group 1 and group 3 innate lymphoid cells in the intestinal lamina propria. Immunity. (2015) 43:146-60. doi: 10.1016/j.immuni.2015.06.019

74. Artis D, Spits H. The biology of innate lymphoid cells. Nature. (2015) 517:293-301. doi: 10.1038/nature14189

75. Buonocore S, Ahern PP, Uhlig HH, Ivanov II, Littman DR, Maloy KJ, et al. Innate lymphoid cells drive interleukin-23-dependent innate intestinal pathology. Nature. (2010) 464:1371-5. doi: 10.1038/nature08949

76. Bhatt B, Zeng P, Zhu H, Sivaprakasam S, Li S, Xiao H, et al. Gpr109a limits microbiota-induced IL-23 production to constrain ILC3-mediated colonic inflammation. J Immunol. (2018)200:2905-14. doi: 10.4049/jimmunol.1701625

77. Guarner F, Malagelada J-R. Gut flora in health and disease. Lancet. (2003) 361:512-9. doi: 10.1016/S0140-6736(03)12489-0

78. Round JL, Mazmanian SK. The gut microbiota shapes intestinal immune responses during health and disease. Nat Rev Immunol. (2009) 9:313-23. doi: $10.1038 /$ nri2515

79. Carding S, Verbeke K, Vipond DT, Corfe BM, Owen LJ. Dysbiosis of the gut microbiota in disease. Microb Ecol Health Dis. (2015) 26:26191. doi: 10.3402/mehd.v26.26191

80. Berry D, Reinisch W. Intestinal microbiota: a source of novel biomarkers in inflammatory bowel diseases? Best practice \& research. Clin Gastroenterol. (2013) 27:47-58. doi: 10.1016/j.bpg.2013. 03.005

81. Brown K, DeCoffe D, Molcan E, Gibson DL. Diet-induced dysbiosis of the intestinal microbiota and the effects on immunity and disease. Nutrients. (2012) 4:1095-119. doi: 10.3390/nu4081095

82. Howe A, Ringus DL, Williams RJ, Choo Z-N, Greenwald SM, Owens SM, et al. Divergent responses of viral and bacterial communities in the gut microbiome to dietary disturbances in mice. ISME J. (2016) 10:1217-27. doi: 10.1038/ismej.2015.183

83. Cummings J, Jenkins D, Wiggins H. Measurement of the mean transit time of dietary residue through the human gut. Gut. (1976) 17:210-8. doi: 10.1136/gut.17.3.210

84. Chassaing B, Miles-Brown J, Pellizzon M, Ulman E, Ricci M, Zhang L, et al. Lack of soluble fiber drives diet-induced adiposity in mice. Am J Physiol Gastrointest Liver Physiol. (2015) 309:G528-41. doi: 10.1152/ajpgi.00172.2015

85. Alou MT, Lagier J-C, Raoult D. Diet influence on the gut microbiota and dysbiosis related to nutritional disorders. Hum Microbiome J. (2016) 1:3-11. doi: 10.1016/j.humic.2016.09.001

86. Buford TW. (Dis) Trust your gut: the gut microbiome in agerelated inflammation, health, and disease. Microbiome. (2017) 5:80. doi: 10.1186/s40168-017-0296-0

87. Solas M, Milagro FI, Ramírez MJ, Martínez JA. Inflammation and gut-brain axis link obesity to cognitive dysfunction: plausible pharmacological interventions. Curr Opin Pharmacol. (2017) 37:87-92. doi: 10.1016/j.coph.2017.10.005

88. Zou J, Chassaing B, Singh V, Pellizzon M, Ricci M, Fythe MD, et al. Fiber-mediated nourishment of gut microbiota protects against diet-induced obesity by restoring IL-22-mediated colonic health. Cell Host Microbe. (2018) 23:41-53. e44. doi: 10.1016/j.chom.2017.11.003

89. Martinez KB, Leone V, Chang EB. Western diets, gut dysbiosis, and metabolic diseases: are they linked? Gut Microbes. (2017) 8:130-42. doi: 10.1080/19490976.2016.1270811

90. Priyadarshini M, Kotlo KU, Dudeja PK, Layden BT. Role of short chain fatty acid receptors in intestinal physiology and pathophysiology. Compr Physiol. (2018) 8:1091-115. doi: 10.1002/cphy.c170050

91. Mukhopadhya I, Segal JP, Carding SR, Hart AL, Hold GL. The gut virome: the 'missing link'between gut bacteria and host immunity? Ther Adv Gastroenterol. (2019) 12:1756284819836620. doi: $10.1177 / 1756284819836620$

92. Rooks MG, Garrett WS. Gut microbiota, metabolites and host immunity. Nat Rev Immunol. (2016) 16:341-52. doi: 10.1038/nri.2016.42

93. Levy M, Blacher E, Elinav E. Microbiome, metabolites and host immunity. Curr Opin Microbiol. (2017) 35:8-15. doi: 10.1016/j.mib.2016.10.003 
94. Kelly D, Conway S, Aminov R. Commensal gut bacteria: mechanisms of immune modulation. Trends Immunol. (2005) 26:326-33. doi: 10.1016/j.it.2005.04.008

95. Atarashi K, Tanoue T, Shima T, Imaoka A, Kuwahara T, Momose Y, et al. Induction of colonic regulatory $\mathrm{T}$ cells by indigenous Clostridium species. Science. (2011) 331:337-41. doi: 10.1126/science.1198469

96. Smith PM, Howitt MR, Panikov N, Michaud M, Gallini CA, Bohlooly-Y M, et al. The microbial metabolites, short-chain fatty acids, regulate colonic Treg cell homeostasis. Science. (2013) 341:569-73. doi: 10.1126/science.1241165

97. Frank DN, Amand ALS, Feldman RA, Boedeker EC, Harpaz N, Pace NR. Molecular-phylogenetic characterization of microbial community imbalances in human inflammatory bowel diseases. Proc Natl Acad Sci USA. (2007) 104:13780-85. doi: 10.1073/pnas.0706625104

98. Wang T, Cai G, Qiu Y, Fei N, Zhang M, Pang X, et al. Structural segregation of gut microbiota between colorectal cancer patients and healthy volunteers. ISME J. (2012) 6:320-9. doi: 10.1038/ismej.2011.109

99. Hamer HM, Jonkers D, Venema K, Vanhoutvin S, Troost F, Brummer RJ. The role of butyrate on colonic function. Alim Pharmacol Ther. (2008) 27:104-19. doi: 10.1111/j.1365-2036.2007.03562.x

100. Coombes JL, Siddiqui KR, Arancibia-Cárcamo CV, Hall J, Sun C-M, Belkaid $\mathrm{Y}$, et al. A functionally specialized population of mucosal CD103+ DCs induces Foxp3 + regulatory T cells via a TGF- $\beta$-and retinoic acid-dependent mechanism. J Exp Med. (2007) 204:1757-64. doi: 10.1084/jem.20070590

101. Manicassamy S, Reizis B, Ravindran R, Nakaya H, Salazar-Gonzalez RM, Wang Y-C, et al. Activation of $\beta$-catenin in dendritic cells regulates immunity vs. tolerance in the intestine. Science. (2010) 329:849-53. doi: $10.1126 /$ science. 1188510

102. Mombaerts P, Iacomini J, Johnson RS, Herrup K, Tonegawa S, Papaioannou VE. RAG-1-deficient mice have no mature B and T lymphocytes. Cell. (1992) 68:869-77. doi: 10.1016/0092-8674(92)90030-G

103. Feng W, Wu Y, Chen G, Fu S, Li B, Huang B, et al. Sodium butyrate attenuates diarrhea in weaned piglets and promotes tight junction protein expression in colon in a GPR109A-dependent manner. Cell Physiol Biochem. (2018) 47:1617-29. doi: 10.1159/000490981

104. Wächtershäuser A, Stein J. Rationale for the luminal provision of butyrate in intestinal diseases. Eur J Nutr. (2000) 39:164-71. doi: 10.1007/s003940070020

105. Cresci GA, Bush K, Nagy LE. Tributyrin supplementation protects mice from acute ethanol-induced gut injury. Alcohol Clin Exp Res. (2014) 38:1489-501. doi: 10.1111 /acer.12428

106. Salem HA, Wadie W. Effect of niacin on inflammation and angiogenesis in a murine model of ulcerative colitis. Sci Rep. (2017) 7:1-8. doi: 10.1038/s41598-017-07280-y

107. Kurnasov O, Goral V, Colabroy K, Gerdes S, Anantha S, Osterman $A$, et al. NAD biosynthesis: identification of the tryptophan to quinolinate pathway in bacteria. Chem Biol. (2003) 10:1195-204. doi: 10.1016/j.chembiol.2003.11.011

108. Gazzaniga F, Stebbins R, Chang SZ, McPeek MA, Brenner C. Microbial NAD metabolism: lessons from comparative genomics. Microbiol Mol Biol Rev. (2009) 73:529-41. doi: 10.1128/MMBR.00042-08

109. Bardhan K, Paschall AV, Yang D, Chen MR, Simon PS, Bhutia YD, et al. IFN $\gamma$ induces DNA methylation-silenced GPR109A expression via pSTAT1/p300 and H3K18 acetylation in colon cancer. Cancer Immunol Res. (2015) 3:795805. doi: 10.1158/2326-6066.CIR-14-0164
110. Li Y, Kundu P, Seow SW, de Matos CT, Aronsson L, Chin KC, et al. Gut microbiota accelerate tumor growth via c-jun and STAT3 phosphorylation in APC Min/+ mice. Carcinogenesis. (2012) 33:1231-8. doi: $10.1093 /$ carcin/bgs137

111. Offermanns S. Hydroxy-carboxylic acid receptor actions in metabolism. Trends Endocrinol Metab. (2017) 28:227-36. doi: 10.1016/j.tem.2016.11.007

112. Plaisance EP, Lukasova M, Offermanns S, Zhang Y, Cao G, Judd RL. Niacin stimulates adiponectin secretion through the GPR109A receptor. Am J Physiol Endocrinol Metab. (2009) 296:E549-58. doi: 10.1152/ajpendo.91004.2008

113. Plaisance EP, Grandjean PW, Brunson BL, Judd RL. Increased total and high-molecular weight adiponectin after extended-release niacin. Metabolism. (2008) 57:404-9. doi: 10.1016/j.metabol.2007.10.018

114. Wang N, Guo D-Y, Tian X, Lin H-P, Li Y-P, Chen S-J, et al. Niacin receptor GPR109A inhibits insulin secretion and is down-regulated in type 2 diabetic islet beta-cells. Gen Comp Endocrinol. (2016) 237:98-108. doi: 10.1016/j.ygcen.2016.08.011

115. Tieu K, Perier C, Caspersen C, Teismann P, Wu D-C, Yan S-D, et al. $\mathrm{D}-\beta$-Hydroxybutyrate rescues mitochondrial respiration and mitigates features of Parkinson disease. J Clin Investig. (2003) 112:892-901. doi: 10.1172/JCI200318797

116. Van der Auwera I, Wera S, Van Leuven F, Henderson ST. A ketogenic diet reduces amyloid beta 40 and 42 in a mouse model of Alzheimer's disease. Nutr Metab. (2005) 2:28. doi: 10.1186/1743-7075-2-28

117. Puchowicz MA, Zechel JL, Valerio J, Emancipator DS, Xu K, Pundik S, et al. Neuroprotection in diet-induced ketotic rat brain after focal ischemia. J Cerebr Blood Flow Metab. (2008) 28:1907-16. doi: 10.1038/jcbfm.2008.79

118. Hu Z-G, Wang H-D, Qiao L, Yan W, Tan Q-F, Yin H-X. The protective effect of the ketogenic diet on traumatic brain injury-induced cell death in juvenile rats. Brain Injury. (2009) 23:459-65. doi: 10.1080/02699050902788469

119. Gurujeyalakshmi G, Wang Y, Giri SN. Taurine and niacin block lung injury and fibrosis by down-regulating bleomycin-induced activation of transcription nuclear factor- $\mathrm{B}$ in mice. J Pharmacol Exp Ther. (2000) 293:82-90.

120. Cho K-H, Kim H-J, Rodriguez-Iturbe B, Vaziri ND. Niacin ameliorates oxidative stress, inflammation, proteinuria, and hypertension in rats with chronic renal failure. Am J Physiol Renal Physiol. (2009) 297:F106-13. doi: 10.1152/ajprenal.00126.2009

121. Ma X, Luo X, Zhou S, Huang Y, Chen C, Huang C, et al. Hydroxycarboxylic acid receptor 2 is a Zika virus restriction factor that can be induced by Zika virus infection through the IRE1-XBP1 pathway. Front Cell Infect Microbiol. (2019) 9:480. doi: 10.3389/fcimb.2019.00480

Conflict of Interest: The authors declare that the research was conducted in the absence of any commercial or financial relationships that could be construed as a potential conflict of interest.

Copyright (C) $2021 \mathrm{Li}, \mathrm{McC}$ afferty and Judd. This is an open-access article distributed under the terms of the Creative Commons Attribution License (CC BY). The use, distribution or reproduction in other forums is permitted, provided the original author(s) and the copyright owner(s) are credited and that the original publication in this journal is cited, in accordance with accepted academic practice. No use, distribution or reproduction is permitted which does not comply with these terms. 